\title{
Isolation and Integration: Case Study of Latter-Day Saints in South-Western Nigeria
}

\author{
Amaechi Henry Okafor
}

Citation: Okafor, Amaechi Henry. 2021. Isolation and Integration: Case Study of Latter-Day Saints in SouthWestern Nigeria. Religions 12: 445. https://doi.org/10.3390/rel12060445

Academic Editors: Matthew Bowman, Caroline Kline and Amy Hoyt

Received: 25 April 2021

Accepted: 7 June 2021

Published: 16 June 2021

Publisher's Note: MDPI stays neutral with regard to jurisdictional claims in published maps and institutional affiliations.

Copyright: (C) 2021 by the author Licensee MDPI, Basel, Switzerland. This article is an open access article distributed under the terms and conditions of the Creative Commons Attribution (CC BY) license (https:// creativecommons.org/licenses/by/ $4.0 /)$.
Department of History, Concordia University, Montreal, QC H3G 1M8, Canada; okafor.henama@gmail.com
Abstract: Isolation and integration are two sides of the same coin, the former denoting negativity with the latter denoting positivity. The penetration of the LDS church into Nigeria in general and south-western Nigeria in particular has been faced with a considerable amount of opposition from the populace and the government. Nigeria is one of the most religious countries in Africa. Due to the vast demographic space, I am limiting our study to the south-western states, where it seems the church is growing more. The eastern region, to an extent, has also been experiencing considerable growth. Our queries are: what are the elements that depict isolation from other religious sects and society? What are the parameters for this phenomenon? Is there any evidence of integration? If so, how is this manifested? How are the male and female members of the LDS church trying to integrate into society and how has the response been? These among other questions are examined. Nigeria is originally a Catholic and Pentecostal religious environment, where open miracles, wonders and other phenomena are visible. These are hardly visible in LDS services, and this serves as motivation for non-members to oppose and isolate members of the LDS church from the fibers of society. The undetermined position of the LDS church and its non-registration with the Christian Association of Nigeria (CAN) has and continues to have relevant effects on the integration of the church and its members into the Christian circle of the country in general and the south-west in particular. I have discovered that, though the church's growth in the south-west is visible, the possibility of integration has proven difficult. Due to the limited literature on this subject in the country, I have utilized semi-structured direct and indirect interviews of pioneers of the wards/units in the south-west, and also those who have investigated the church, many of whom still view the church as a cult. I also used an analytic approach that straddles critical discourse analysis and postcolonial theory. This paper proposes ways in which the members of the LDS church can better integrate themselves in a society that has a very different religious and cultural background to that of American society, where the church has more fully moved from isolation to integration.

Keywords: integration; isolation; segregation; Pentecostal; Catholic; investigators; non-members; members; pioneers

\section{Introduction}

The members of the Church of Jesus Christ of Latter-day Saints (LDS church) in Nigeria are quite different compared to their counterparts in the western world. Africa in general is a very religious continent and Nigeria one of the most religious amongst all African countries. This paper evaluates and elaborates the religious experiences of Latter-day Saints (also known as Mormons) in Nigeria's south-western states and examines how these Latter-day Saints have evolved from their previous identity and religious society. Most of the active members in Nigeria were formerly Pentecostal, Catholic, Methodist, Anglican or Baptist, and the practices in their previous religious bodies still have a hold on them. Most find it difficult to adapt to the ways of the LDS church.

The Mormons in Africa attach cultural values to religious worship, and this has been the trend since Christianity found its way into vast regions of the African continent through colonization. Colonizers used religion and education to integrate into the colonies. This 
gave birth to the first churches and schools in Nigeria. Amongst the first churches were Catholic and Anglican churches, which saw the need to include Nigerian cultural practices into worship. The LDS church, in contrast, does not integrate Nigerian cultural practices into their worship services. Many Nigerians today consider the LDS church to be a cult because some of its practices are associated with secrecy. Nigerians associate cults with fetishism and practices such as blood spilling. Speculation as to the exact nature of LDS religious practices abounds.

A very brief introduction to the main ethnic groups and regions in Nigeria is order, as different regions have experienced LDS church growth at different rates. The main groups, each with distinct languages, are Yorubas, Hausas and Igbos, and they determine to a large extent the growth of the LDS church. The church has a very small presence in the northern region, occupied by the Hausas. Igbos tend to occupy the eastern parts of Nigeria, and the church has experienced growth there in recent years. Nigerians in the south-western regions, who are mostly Yorubas, prize education. English is highly valued in the south-west, and church membership is growing there.

This paper evaluates ways in which LDS church members, mostly Yorubas from south-western Nigeria, experience a state of isolation from friends, families and neighbors in their religious and social cadres because of their membership to a church often perceived to be a cult. It also evaluates the ways they are trying to move from that state of isolation to integration and adaptation to their new identity as members of the LDS church. In this article, isolation entails distance, separation and an inability to relate to other people who are not members of one's religious community because of misconceptions about that community. Integration, on the other hand, entails people freely identifying as members of the LDS church while freely relating to others in their community, irrespective of religious affiliation. With limited academic resources on this topic, I use analytical tools such as semi-structured interviews and literary theories about identity. My work is going to be as practical as possible. As a Nigerian Latter-day Saint myself with a personal interest in this topic, I want to examine what elements are responsible for the integration and isolation of Mormons in Nigeria.

The LDS church has an estimated 193,000 members in Nigeria, and the fact remains that most-especially those who converted to the church from other religious sects-still find it challenging to integrate as members of the LDS church into Nigerian society and culture. While other churches embrace indigenous languages and traditional drums and music, the LDS church does not, which makes the LDS church look odd to people who are used to their religious practices, including indigenous African elements. Additionally, Nigerians overwhelmingly believe in signs and wonders, but most members do not see this on open display in the LDS church. This makes them attend LDS and their former churches on a rotating schedule. I conclude that the church still needs to find a way to integrate African culture into the LDS religious setting, similar to what was achieved in Tonga and Samoa. Goman (2006) describes the process of adapting Samoan cultural clothing into LDS church practice and dress standards as a novel way of integrating culture into the LDS religion.

\section{Literature Review}

How am I using and defining identity in this paper? Francis Deng, as cited by Chan (2013), defines identity as "the way individuals and groups define themselves and are defined by others on the basis of race, ethnicity, religion, language and culture" (p. 19). Bhabha's (1994) perception of identity relates to the term he describes as hybridization-a situation in which an individual or group possesses two or more cultural, religious, or ethnic identities and tries to integrate into them. Frantz Fanon, in Black Skin, White Masks (Fanon 1967), reiterates the damages of colonization and neocolonization on the identities and way of life of the colonized. Identity in Africa boils down to various factors-before, during, and after colonization. There is a mix-up of culture, according to Hui (2005), who describes such cultures as civic cultures; in other words, a civic culture is one which is not 
modern but a mixture of old culture with the invaders' culture. Identity and its evolving state become major topics for discourse, especially when they concern Africans and religion. Bhabha's (1990) term unhomliness, which describes people who are neither here nor there, applies to LDS converts who cannot really determine whether they are Mormons or still adherents to their former religious sects.

\section{Elements of Isolation in South-Western Nigeria}

Some Mormons in Nigeria have a difficult time figuring out how they came to a state in which they have been disconnected from other Christian sects and isolated in their status as members of a minority religious tradition which is not widely understood or accepted. Due to the stigma against Mormons-many believe the LDS church is a cult-some members do not feel as if they can categorically say they are members of the church in some societal circles. Members of religious denominations which have been present in the country since the era of colonization often have a different experience. While these religions and churches were brought to Nigeria through colonization, a fact that is troubling to some adherents, members of these other churches have been fully integrated into the Nigerian societal fabric, thus allowing them to better fit into Nigerian culture, especially Nigerian religious culture. The use of drums and African musical instruments are part of the foundations of the two main religious sects in Nigeria, Pentecostalism and Catholicism. The LDS church, on the other hand, does not allow the use of African musical instruments in worship services. This contributes to Nigerian LDS members feeling isolated from important cultural elements as they worship.

I interviewed some members of the LDS church, and they made various points about how they feel unhomely - neither here nor there-when issues of religion are brought up. Onome Alfred (2020) discussed the difficulties most members find themselves in when they consider issues of western religion, colonization, and African life and culture: "I actually do not really trust western religion to an extent. Yes, we know that Jesus Christ and God ... we know that they are God, but the thing is the whites brought religion to us, and ... when religion came to Africa, African[s] became worse" (p. 20). Alfred manifests a certain amount of ambivalence towards western religion, pointing to the fact that it is alien to Nigerian traditional practices. Some religious sects have therefore incorporated African practices and cultural elements into their worship. The LDS church, however, still promotes western cultural practices which are alien to traditional Nigerian practices. This leaves the members in an in-between state where they cannot live as Nigerians or Mormons.

These western cultural practices, so embedded in Mormon practice, lead to feelings of displacement, dislocation and isolation. Eniola Bakare (2019) described the isolation she feels as a member of the LDS church when she said, "I most time feel scared in the midst of non-members because they see me as a different being" (p. 2). As Mormon worship services are so different and do not include Nigerian practices of exuberant singing and dancing, the LDS church is often viewed as a cult by other Nigerians. Bakare's presence in public spaces is viewed with distrust, as people do not want to mix with members of a sect that is so solemn and associated with white people. She further explains that most of the time she prefers remaining isolated rather than trying to blend in with her neighbors. Mixing with people in her neighborhood tends to lead to contentions given the frequency with which religious conversations occur.

I also interviewed a man in a ward in Abeokuta who insisted he remain anonymous. Having been converted from the Apostolic Church, a Pentecostal tradition, he has found it difficult to adapt to the culture of Mormonism. He stated that the quiet state of the church services still amazes him because he is used to praying with loud clapping. He said, "In my former church, we dance and sing, but here I feel drowsy most times during service" (2018). He said that, for the first year as a member of the LDS church, he spent most of sacrament meeting (the main worship service) sleeping because it all seemed boring and quiet to him. Godswill Onourah (2020) reiterated this disconnect between Nigerian expectations of energy, dancing and clapping at church and the realities of the quiet services in the LDS 
church. He once invited a friend to his LDS congregation's worship service, and his friend was not attracted to the solemn tone of the meeting. Onourah said, "A friend of mine said one time that she cannot go to somewhere that's not bubbling ... somewhere that is like too silent ... Somewhere that's, you know where the spirit is not moving ... She just wants to dance, shout and scream, that's what she wants to do" (p. 6). Most other churches in Nigeria, having merged religion and Nigerian cultural practices such as dancing and singing, build their services around this kind of energetic and loud worship. Onourah also said that he found it difficult to explain the type of denomination he belonged to when confronted by friends, so he just avoids discussing the LDS church.

In Nigeria, most people are either Pentecostals (having over a hundred denominations), Catholics, Anglicans, Methodists, Baptists or members of the Celestial Church of Christ. The level of hybridity the members of the LDS church in Nigeria possess is quite different from that of their counterparts in the United States, who are generally able to more seamlessly blend the conservative western values and practices embraced by Mormonism with cultural elements in their immediate communities. For Nigerians, it is often problematic to embrace the various identity dichotomies that are encouraged by the doctrines of the LDS church and supported by African cultural norms. For example, the LDS dichotomy of male/female, which places man as presider and head of the home, actually intensifies patriarchal patterns already present in Nigerian society, which tend to give men full control of the house and promote female obedience without question. Other dichotomies, such as Muslim/Christian, might also be intensified in an LDS context in Nigeria.

Having researched the factors and elements affecting the isolated state of some members of the church in south-western Nigeria, I noticed the sense of isolation is also linked to the cultural heritage of the converted individuals. It is important to state that not all LDS church members are Yoruba, which is the ethnic language of the south-western region. We have members living in the south-west who are originally from the Igbo speaking part of the country, and these individuals face a trio of isolations: first as LDS members in larger society, then as members within the church itself and, finally, as Igbos in larger society. This isolation stems primarily from their ethnicity. Nwoagu John (2018) from the Ibadan North Stake confirmed this point, saying he feels marginalized in the church because of the level of ethnic bigotry: "I am seen as an outsider when spiritual things are discussed or a calling is coming through, just because I am not Yoruba." He further says that his membership in the LDS church tends to pose a lot of problems for his neighbors, who find his religion strange and unexplainable. Fatimah Angela (2020), a native of Sierra Leone, emphasizes this point when she states that callings are given based on ethnic groups: "Most of the time if you check where I'm living in Ibadan [Nigeria], most of the people that have the callings they are Yorubas ... Yes, especially in Ibadan. You don't see foreigners here, and if we don't have foreigners in the church I will say maybe it's us ... Maybe like Igbos. Other people like that they don't give them callings like that" (p. 18). This tendency to give callings, particularly prominent callings, to the dominant ethnic group evidently encourages isolation, even within the LDS church in Nigeria.

Isolation also boils down to the use of English as the sole language of instruction in LDS church services in south western Nigeria. Most non-members who are interested in the church complain of their incomprehension of discussions during services. Angela gives us insight into the uncomfortable dynamics that members encounter when they do not understand the services or classes because they are in English. She said, "When I went home to Sierra Leone, you know we speak Krio ... This people don't understand this English very well, the Queen's English, very well. So Krio is what they will understand. So when I got to Sierra Leone, I [didn't] understand Krio very well, so when I speak [it is] in English ... In the church, most of them I found out that they don't get me well ... They don't not understand what I'm saying. So after, when I'm finished, the Relief Society sister will have to come back and summarize what I was saying in Krio before they can understand what I was saying" (p. 15). There is a kind of frustration experienced by people who are speakers of native African languages but non-fluent or illiterate in 
English. These non-fluent English speakers struggle to understand LDS church services properly. Language is an important cultural factor, and some members in Nigeria feel that comprehension, participation and investment can be lost when services are held in English. When I was interviewed for an oral history project, I myself commented on this frustration:

Some just come and sit, attend the church. After service they go home. They don't really understand, they don't get the concept of it. Liahonas can be in Yoruba, you know, can be in Hausa, can be in Igbo. That is what I'm saying. You know, when I hear they say Liahona is fifty something [in fifty languages] I just see French. What makes French better than Yoruba? You understand what I'm saying? What makes the German language better than the Igbo language? You see? If the church can invest much in translating those documents to those language I think they should invest that much in translating the documents to Swahili, to Yoruba, to Efik. Look at the Yoruba the major. You can actually translate to all minor language, but look at the major language. Like in Nigeria we have three major languages: Yoruba, Hausa, Igbo. If you translate to the three major languages-now the church is not really in the North because, one, the Hausa-most of them don't not really understand English, but when they see the scripture and everything in Hausa, you have more conversion." (Amaechi Okafor 2020, p. 19)

This frustration over English-only worship services and church classes is a form of isolation from an important element of people's culture. As the LDS church tries to take root in Africa, there has to be consideration for the culture and language of the indigenous people. There is already an inherent danger of traditional language loss, as some Nigerians would rather teach their children English than their traditional language. Some Nigerians fear that, in the near future, the Igbo language will be spoken by few Nigerians. This would be a significant cultural loss for this ethnic group, and the LDS church could play a part in preserving a very important aspect of traditional culture by encouraging worship services to take place in traditional languages such as Igbo.

I also distributed a questionnaire in a ward in which a significant number of members indicated they were undecided whether they really had integrated into their various local communities. The majority of respondents reported that they could hardly talk about religion in their communities, thus isolating them from the happenings of their immediate environment. It is pertinent to state here that there are remote and immediate causes for the isolation members feel from their immediate societies. Among the causes, I have singled out religion, culture, norms and language. Sometimes, members of the LDS church are also isolated due to their employment status and self-reliance capabilities. Many members struggle to find or maintain employment because of their religious affiliations and beliefs, since so many Nigerians believe the church to be a cult. Often, when applying for a job, application forms ask about religious affiliation, and employers sometimes avoid hiring members of the LDS church. I interviewed a member who stated that he worked as a gateman in one of the popular Pentecostal churches but later met with missionaries and was baptized. He was fired because of his conversion and has remained unemployed. Additionally, his family and close associates blame him for his conversion, saying they perceive the church to be a cult, thus isolating from them. He stays away from his friends and family to avoid discussions on the subject. This type of situation has been reported by seven members, whom I interviewed across the south-western Nigerian states of Oyo, Osun, Ondo and Lagos.

The African belief in the mystical is also important context for the isolation which so many Latter-day Saints experience. In African Traditional Religion (ATR), there is a fusion of song, dance and spiritual practices. These activities are believed to summon the presence of some communal deities. The practice of using drums, songs and dancing in ATR has been adopted by some Christian religious bodies, though they make affirmations to Jesus Christ and do not invoke any form of traditional deities. Most Nigerians want to see open display of miracles and exuberant spirituality, as they are performed in popular Pentecostal churches. With this not visible in the LDS church, most people are discouraged 
from associating with or becoming members of this church. A good number of members still attend services in their former churches, but none agreed to discuss this on record. The exclusivity claims of the LDS church-that the LDS church is the only true church of Jesus Christ and the only one to have legitimate priesthood authority-encourage secrecy about this. Many Nigerians quietly shuffle between the LDS church and other churches, hiding their LDS identity in order to gain access to other religious communities. This leads to a hybridization of religious identity, but it is a lonely state, as people feel unable to be truthful about their religious affiliations and are not fully integrated into any religious community.

Hybridization is especially common among those members who are married to nonmembers. There have been instances where women who are members have husbands who attend Pentecostal churches, thus leading to a level of mental isolation for these women. This isolation occurs because members of the family might decide to go to separate churches, thus fostering a form of division in the family. This is applicable to male members who are married to non-members. Sometimes, if care is not taken, these individuals could fall away from the LDS church. This is because their partner often becomes hostile to the LDS church, maybe due to its influence on family members, associates, colleagues, or members of their immediate community. This is affirmed by Akpan John (2019) when he said, "I find it difficult to be free with my family because my wife is not a member and her family disapproves of my membership ... . I attend my wife's church sometimes to maintain peace" (p. 3). In order to save their marriages, some members become inactive. This is one among various factors that are responsible for the isolation members feel in their communities.

\section{Elements of Integration in South-Western Nigeria}

Though this is ongoing research, the situation regarding Mormons in south-western Nigeria cannot all be negative. Some members integrate well into their various societies. Different factors are responsible for this, and I base my findings on the oral history project I conducted for Claremont Graduate University in 2020 and some semi-structured interviews I conducted between 2017 and 2019.

I observed that many members are accepted in their societies as honest and kind people. Kindness and honesty are praised cultural attributes in Africa-they are visible in folklore and moonlight stories, which are indigenous knowledge systems that existed before the arrival of western civilization. For example, Adebanjo Rasaq (2019) said that he has enjoyed great integration in his society because his neighbors respect his integrity and honesty, and they attribute these character traits to his membership in the LDS church. Though his neighbors are not willing to become members, they are willing to attend church social activities (p. 4). Doris Babalola (2018) said she is seen as a well-cultured individual because she balances culture with religion. (p. 3) This was supported by Ekikere Ayodele (2020), who advocates good cultural practices for her husband's family, who are Yorubas: "Well, being a member of the Church, we cannot change their culture but rather we can talk to the people. Like, I do try to speak with my family concerning their culture, that they should also see that the scriptures refer to this as foolish traditions of their fathers because they don't know" (p. 13). During the interview, she states that, due to her integration, she has been able to establish a school and have people trust her with the education of their kids, both culturally and morally. Ayodele has literally hybridized: "I learned to adapt to it. Their food-I learnt to like the food. And I learnt to appreciate their culture" (p. 16).

Since the south-west is a region known for education and intellectuality, the LDS church has grown more and has become more integrated because of the number of educated elites in the south-west compared to the north or east. The church is seen to belong to elites and is generally not considered a religion for people without knowledge of English or from a poor background. It is important to note that location matters in issues of integration. Church branches and wards in the urban and rural areas are different, as the former are stronger than the latter because of education and literacy. There are more educated individuals in urban areas compared to rural areas because of rural people's agricultural 
preoccupations. The church is looked upon as a panacea of better English for all, thus making it attractive to a group of individuals who would like to become good English speakers. This results in the integration of some rural non-members who become members, though not a considerable number. These rural Nigerians often speak Yoruba, which is favored in rural environments, and rural Pentecostal churches conduct their services in local languages, generally Yoruba, with an English interpreter. This encourages native speakers to visit these churches more, compared to the LDS church. The margins of integration in the rural and urban centers are different, possibly because, in rural communities, traditional practices are more emphasized. This was affirmed by Elias Sanni (2019), who migrated from a branch in a rural area of the church to a ward in urban Ibadan. He stated, "You know I interviewed someone and he told me the church is growing more in Ogbomoso [a rural area] because they use Yoruba mostly, and that is one of my point. You know, when you take the language of the people from them, you are gradually killing their culture" (p. 2). The predominant use of the Yoruba language aided him in integrating easily into the branch, as he is from Ogbomosho, a rural village. However, due to the English which is also spoken and promoted in his branch, he was able to easily acclimatize to the new ward and society, where English was the predominant language.

Some members also integrate into religious circles. Various members try to foster friendships with people from other religious sects, even Muslims, making the LDS church's presence known. I spoke with a bishop who asked to remain anonymous, and he said he tries to enact deeds of charity that will make it easy for members to better integrate into their immediate communities, especially those living close to church buildings. He said he allows members and non-members to use the church compound for wedding receptions free of charge, with the condition to clean the building. He allows Muslims to use the space, and this has opened his ward up to creating connections with many people in the community. (2019, p. 2) I confirmed this story with a member of a Muslim family, Mr Azeez, who said he was amazed at the gesture of the church; it saved him money he would have needed to spend on a wedding/reception hall. This is an instance of one ward's integration into a Muslim-dominated area. My questionnaire indicated that members more easily integrate into their societies by being religiously tolerant.

The level of integration could also depend on marital relationships. I have interviewed Latter-day Saint women who have confirmed that their husbands are non-members who are in agreement with their membership, thus giving the woman, or man in some cases, the stable identity of a member, as well as the acceptance as such in his/her community. Community is extremely important in Nigeria, which is a country with various cultures that encourage communal living, where everyone knows who their neighbor is and can say something substantial about him or her, including details about his or her religious practice.

With various programs of the church, such as the Mormon Helping Hands and Mormon charities, the church has created a presence in the religious and social networks of the region. There have been instances, as recounted by members, where their social activities have helped and continue to help society. Bishop Oyebanji (2020) said, "I love to dabble into other profession, even having most of the tools of other professions. And then with the teachings of LDS, still teaching us about self-reliance in most of the things, I love to continue to ensure that I engage in practical things" (p. 19). Some of these charitable and self-reliance programs have therefore served as successful integrative devices for new members. The opportunity to gain education through BYU-Pathway Worldwide is another tool that has been used for integrative purposes. The program allows members and non-members to obtain degrees from the church-owned university, BYU-Idaho. The south-west is a region where education is highly valued, so many people want to take the opportunity to attain education through a university in the U.S. This was affirmed by a new member who preferred to remain anonymous. He said his parents only allowed him to become a member when he told them of his educational aspirations. 


\section{Building towards More Integration}

Both isolation and integration are important markers of experience for Latter-day Saints in Nigeria, and these experiences are determined by how members see themselves and interact in their immediate societies. Nigeria is a religiously tolerant country with thousands of churches and faithful members, so members of the LDS church are considered religiously free individuals. Despite their religious standing of not being registered with the Christian Association of Nigeria (CAN), the church has gained a certain level of integration, though there are still various stereotypes against the church and its members. The government of Nigeria is liberal with religious institutions and allows them to practice under the constitutional limits. There are various religious practices in Nigeria, from Islam to Christianity and the African Traditional Religion (ATR), which has gained its own ground on the religious stage. ATR has grown in recent years because of the revival of cultural practices by scholars. Academic institutions encourage traditional dance, festivals and indigenous knowledge systems found in folklore and the worship of indigenous deities.

The church can become a stronger presence in Nigeria by better integrating into local communities and coming out of the shadows. One way this can be achieved is by integrating cultural elements such as drums, clothing and indigenous languages into church worship. Nigeria is a society where churches advertise on radios, but the LDS church never indulges in this kind of publicity. Nigerians tend to believe that the LDS church is a cult organization because there is so little open conversation about the church and its mission via broadcasts on local radio and television stations. This was affirmed by a good number of interviewees in the oral history project for Claremont Graduate University, who discussed the widespread belief among many Nigerians that the LDS church is a cult. Some Nigerians have investigated the church and its activities just to know for sure about its status as a cult. I spoke to two investigators during our tour of wards in the southwest, and they stated their staunch faithfulness to their various Pentecostal religious sects. However, they decided to investigate the church, as they do not see anything on television or hear anything on radio about this church. This lack of publicity and advertising can be a barrier to the integration of the church into the region. More research needs to be performed analyzing the factors obstructing the integration of the LDS church and its members into the Nigerian societal and religious fabric.

\section{Conclusions}

The integration and isolation of Mormons in the south-west has been an area of interest to many individuals who looked forward to granting interviews on this subject. The level of integration is increasing, though there are still obvious elements of isolation that needs to be addressed. I recommend further research on the isolative and integrative studies on Mormon identity in Africa. Naturally, Africa is a ground of religious sentiments built around imported religion mixed with traditional and cultural elements, and Pentecostal churches have been successful in integrating cultural and religious norms together to birth a hybrid religion that is applicable in Nigerian demography. The LDS church, on the other hand, is perceived as elite given its pervasive use of English in its services, as well as it being conservative in its public relations in societies where they have established a presence. It is also perceived as strikingly foreign in its quiet worship style, solemn hymns and clothing norms that are unusual in Nigeria. Finally, church programs or classes discussing indigenous Nigerian culture and values might aid the integration of Nigerian cultural elements into the LDS experience in Nigeria.

To attract and retain LDS members in Nigeria, and to foster better relationships with its non-member neighbors, the church should increase its publicity and publicize more information about itself. The Nigerian populace is very inquisitive, so the church needs to perform work more in its integrative policies. Encouraging indigenous languages in their services is one important way for the church to integrate into local Nigerian communities. Most people interviewed, even the non-Yoruba, said they would prefer it if the services could be in English and Yoruba. This is common in the Pentecostal and Catholic churches, 
where indigenous languages are also used. The language barrier will continue to militate against the growth of the LDS church in south-west Nigeria because some rural dwellers are monolingual and can only understand Yoruba. They cannot cope with the English LDS services in their various wards and branches, and the church will therefore remain out of reach for a significant portion of the Nigerian population.

Funding: This research received no external funding.

Institutional Review Board Statement: This research was approved by the Claremont Graduate University archives, where I was actively responsible for the oral interviews used in this paper. The study was conducted according to the guidelines of the Declaration of Helsinki, and approved by the Institutional Review Board (or Ethics Committee) of CGU.

Informed Consent Statement: Informed consent was obtained from all subjects involved in the study by an agreement form signed by the interviewees.

Data Availability Statement: Data is available at Claremont Graduate University project titled "The Mormonism and Migration Project" from Nigeria. https:/ /research.cg.edu/mormonism-migrationproject/people/ (accessed on 7 June 2021).

Conflicts of Interest: The author declares no conflict of interest.

\section{Interviews}

Oral history interviews in archive:

Alfred, Onome. (2020, January 30). Interview by Amaechi Okafor in Ibadan Nigeria. Claremont Global Mormon Oral History Collection, \#71, transcript, p. 2, Special Collections, The Claremont Colleges Library, Claremont, California.

Ayodele, Ekikere. (2020, June 14). Interview by Amaechi Okafor in Ibadan Nigeria. Claremont Global Mormon Oral History Collection, \#75, transcript, p. 16, Special Collections, The Claremont Colleges Library, Claremont, California.

Dankyi, Fatima Angela. (2020, July 20). Interview by Amaechi Okafor in Ibadan Nigeria. Claremont Global Mormon Oral History Collection, \#78, transcript, pp. 15, 18, Special Collections, The Claremont Colleges Library, Claremont, California.

Onourah, Godswill. (2020, August 14). Interview by Amaechi Okafor in Ibadan Nigeria. Claremont Global Mormon Oral History Collection, \#79, p. 6, Special Collections, The Claremont Colleges Library, Claremont, California.

Okafor, Amaechi Henry. (2020, September 5). Interview by Opeyemi Oyebanji in Ibadan Nigeria. Claremont Global Mormon Oral History Collection, \#82, transcript, p. 19, Special Collections, The Claremont Colleges Library, Claremont, California.

Oyebanji, Surakat. (2020, April 22). Interview by Amaechi Okafor in Ibadan Nigeria. Claremont Global Mormon Oral History Collection, \#68, transcript, p. 19, Special Collections, The Claremont Colleges Library, Claremont, California.

Oral histories not in an archive:

Babalola, Doris. (2018, December). Interview by Amaechi Okafor in Ibadan, Nigeria, Personal Communication. Bakare, Eniola. (2019, March 13). Interview by Amaechi Okafor in Ibadan, Nigeria, Personal Communication. John, Akpan. (2019, May 15). Interview by Amaechi Okafor in Ibadan, Nigeria, Personal Communication. John, Nwoagu. (2018, July). Interview by Amaechi Okafor in Iyana Ipaja, Nigeria, Personal Communication. Rasaq, Adebanjo. (2019, August 12). Interview by Amaechi Okafor in Oshogbo, Nigeria, Personal Communication. Sanni, Elias. (2019, May 12). Interview by Amaechi Okafor in Ibadan, Nigeria, Personal Communication. Oyebanji, Surakat. (2019, August 11). Interview by Amaechi Okafor in Ibadan, Nigeria, Personal Communication. *Mr Azeez is a Muslim who used the church building in Ibadan for an event.

\section{References}

Bhabha, Homi K. 1990. Nation and Narration. New York: Routledge.

Bhabha, Homi K. 1994. The Location of Culture. London: Routledge.

Chan, Tina. 2013. National Identity Formation in a Post-colonial Society: Comparative Study of Hong Kong and Taiwan. Master's thesis, Central European University, Budapest, Hungary.

Fanon, Frantz. 1967. Black Skin, White Masks. Translated by Charles L. Markmann. New York: Grove.

Goman, Jessica. 2006. Mormonism in Samao: Cultural Dialogues. Unpublished manuscript, Independent Study Project (ISP) Collection, p. 377.

Hui, Kin-kan. 2005. A Comparative Study of the Political Culture of Post-colonial Hong Kong and Macau. The HKU Scholars Hub. Hong Kong: The University of Hong Kong Press, pp. 5-13. 